\title{
The Use of Aloe vera as Natural Coagulant in Algerian Drinking Water Treatment Plant
}

\author{
Abderrezzaq Benalia ${ }^{1,2}$, Kerroum Derbal ${ }^{2, *}$, Amel Khalfaoui ${ }^{1}$, Antonio Pizzi $^{3}$ and Ghouti Medjahdi \\ ${ }^{1}$ Faculty Process Engineering, University of Constantine 3, Constantine, 25000, Algeria \\ ${ }^{2}$ National Polytechnic School of Constantine, Constantine, 25000, Algeria \\ ${ }^{3}$ LERMAB-ENSTIB, University of Lorraine, Epinal, 88000, France \\ ${ }^{4}$ Institut Jean Lamour, Université de Lorraine, CNRS, Nancy, 54011, France \\ *Corresponding Author: Kerroum Derbal. Email: derbal_kerroum@yahoo.fr
}

Received: 11 June 2021 Accepted: 29 July 2021

\begin{abstract}
The purpose of this work is the study the ability of the plant material Aloe vera to act as natural coagulant using raw water obtained from a drinking water treatment plant (Mila, Algeria). Different solvents such as: $\mathrm{NaCl}$; $\mathrm{NaOH}$ and $\mathrm{HCl}$ were used as chemical activators to extract the active components from the Aloe vera plant, and different coagulation-flocculation experiments were conducted in a jar test apparatus to evaluate the performance of the extracted coagulant. Also, the effect of coagulant dose on some water parameters such as turbidity, $\mathrm{pH}$, total alkalinity and organic matter were investigated. The results showed that the use of coagulants obtained by using different solvents increases the coagulation efficiency compared to the coagulant obtained from the raw material, for example the maximum turbidity removal efficiency was $28.23,78.07,83.46$ and $85.15 \%$ when using powdered Aloe vera (raw material), $\mathrm{AV}-\mathrm{NaCl}(0.5 \mathrm{M}), \mathrm{AV}-\mathrm{NaOH}(0.05 \mathrm{M})$ and $\mathrm{AV}-\mathrm{HCl}(0.05 \mathrm{M})$, respectively. The results defined, that the residual turbidity obtained in this work, where the Aloe vera was used (after treatment by solvents) produced a turbidity lower than the Algerian standard (5 NTU) with initial turbidity (13 NTU). In this study, the infrared spectrum study and analysis has revealed the presence of different functional groups, which are responsible for the coagulation process.
\end{abstract}

\section{KEYWORDS}

Actives components; coagulant; colloidal particles; infrared spectrum; solvent

\section{Introduction}

The colloidal particles present in natural waters cannot precipitate and form sediments because of their small size. The operation of coagulation-flocculation aims for the growth of particles (which are essentially colloidal) by destabilization of suspended particles and then the formation of flocs by adsorption and aggregation [1]. The destabilization of suspended entities is achieved through adsorption phenomena [2], explained by the double layer theory. It explains how colloids are treated by coagulation [3,4]. The experimental realization of coagulation flocculation aims to determine the optimal concentration of coagulant necessary for a maximum removal of water turbidity [5]. 
As some studies have shown, coagulants based on aluminum, iron and even synthetic polymers have a significant disadvantage: their proven toxicity to the environment [6] and production of large sludge volumes [7]. Moreover, aluminum is a neurotoxicant and may contribute to Alzheimer's disease [8]. This has led some researchers to study the possibility of using natural coagulants, biodegradable, non-toxic and available to carry out the coagulation-flocculation process [9].

Most plant-based coagulants cannot feasibly used due to their cost and insufficient worldwide availability, making them difficult to use for water treatment. In addition, year-round availability is an important factor to consider.

The use of natural coagulants has been discouraged in developed countries on the grounds that they have never been subjected to rigorous scientific evaluation [10]. In the developing countries, their development has continued so that today they are beginning to take an interest in this alternative [11]. Traditionally, organic coagulants have been used at the household level. Women in rural Sudan treat their water with Moringa oleifera before using it as drinking water [12].

The natural coagulants like Moringa oleifera, Banana pith, Dillenia indica, Lentil, Chitosan, lime, Cactus have been applied to remove the turbidity [13-15], color [16], heavy metals [17], and improve the chemical oxygen demand (COD) [18,19], remove total suspended solids (TSS) [20], nitrates and sulfates [15,17], alkalinity [15], Conductivity [21], biological oxygen demand (BOD) [22], total phosphor [19], total organic carbon [23], sulfide [24], phosphate $\left(\mathrm{PO}_{4}{ }^{3-}\right)$ [22], Escherichia coli and total coliforms [25-27]. The turbidity removal efficiency is significantly influenced by the active components from natural coagulants. Therefore, these active substances are responsible for coagulation, for instance: proteins [23,28]; polyphenols [29], polysaccharide [30], starches [31,32] and cellulose [33].

Various solvents have been used in the process of extraction of active components to enhance the coagulation, namely distilled water [14,34], $\mathrm{KCl}[14,35] \mathrm{NaCl}[34,35], \mathrm{KNO}_{3}$ and $\mathrm{NaNO}_{3}$ [36], $\mathrm{HCl}$ [34], $\mathrm{BaCl}_{2}$ [37], $\mathrm{NaOH}$ [34], $\mathrm{NH}_{4} \mathrm{Cl}$ [7]. Tab. 1 shows the use of some organic coagulant on turbidity removal using several chemicals.

In a test on the extraction of active coagulating agents, different solvents have to be tested and compared, that's why we have used three different solvents: a salt $(\mathrm{NaCl})$, a base $(\mathrm{NaOH})$ and an acid $(\mathrm{HCl})$ to improve the coagulation capacity of Aloe vera and thus turbidity removal efficiency. Aloe vera as a natural based coagulant acts differently than the chemical coagulants. The long chains of proteins catch the colloidal pollutants and suspended solids to form flocs that settle down by gravity. Aloe vera can be an alternative coagulant, which can be used for drinking water treatment by natural coagulation process [38].

Table 1: Turbidity removal by natural coagulants using several chemicals

\begin{tabular}{llllr}
\hline Coagulant & Solvent chemical & $\begin{array}{l}\text { Initial turbidity } \\
(\mathrm{NTU})\end{array}$ & $\begin{array}{l}\text { Removal turbidity } \\
(\%)\end{array}$ & References \\
\hline Cactus & $\mathrm{NaCl}$ & 7.76 & About 80 & {$[37]$} \\
& $\mathrm{H}_{2} \mathrm{SO}_{4}$ & 9.5 & 66.31 & {$[39]$} \\
& $\mathrm{NaOH}$ & 9.5 & 89.26 & {$[39]$} \\
& $\mathrm{Distilled} \mathrm{water}$ & 7.76 & 27.68 & {$[37]$} \\
& $\mathrm{BaCl}_{2}$ & 7.76 & 78.43 & {$[37]$} \\
\cline { 2 - 4 } Moringa oleifera & $\mathrm{KCl}$ & 1674 & 83 & {$[40]$} \\
& $\mathrm{NaCl}$ & 1674 & 89 & {$[40]$} \\
& $\mathrm{Distilled} \mathrm{water}$ & 1674 & 45 & {$[40]$} \\
& $\mathrm{CaCl}_{2}$ & 25.3 & 57.9 & {$[41]$} \\
\hline & & & (Continued)
\end{tabular}


JRM, 2022, vol.10, no.3

\begin{tabular}{|c|c|c|c|c|}
\hline Coagulant & Solvent chemical & $\begin{array}{l}\text { Initial turbidity } \\
\text { (NTU) }\end{array}$ & $\begin{array}{l}\text { Removal turbidity } \\
(\%)\end{array}$ & References \\
\hline \multirow[t]{4}{*}{ Acorn } & $\mathrm{NaCl}$ & 13 & 91.07 & {$[34]$} \\
\hline & $\mathrm{HCl}$ & 13 & 92.92 & [34] \\
\hline & $\mathrm{NaOH}$ & 13 & 85.92 & [34] \\
\hline & Distilled water & 13 & 84.77 & [34] \\
\hline Chestnut & Distilled water & 35 & About 80 & {$[42]$} \\
\hline \multirow[t]{3}{*}{ Fava bean } & Distilled water & 20 & 38 & {$[43]$} \\
\hline & & 45 & 54 & [43] \\
\hline & & 90 & 48 & [43] \\
\hline \multirow[t]{3}{*}{ Jatropha curcas seeds } & $\mathrm{NaCl}$ & 500 & 99.4 & {$[44]$} \\
\hline & $\mathrm{NaOH}$ & 500 & 91.4 & [44] \\
\hline & Distilled water & 500 & 99 & [44] \\
\hline \multirow[t]{2}{*}{ Phaseolus vulgaris seeds } & $\mathrm{NaOH}$ & 500 & About 85 & {$[45]$} \\
\hline & $\mathrm{NaCl}$ & 500 & more than 85 & {$[45]$} \\
\hline \multirow[t]{2}{*}{ Strychnos potatorum } & $\mathrm{NaOH}$ & 500 & About 93 & {$[45]$} \\
\hline & $\mathrm{NaCl}$ & 500 & More than 95 & {$[45]$} \\
\hline Aloe vera gel & Distilled water & 186.8 & 72 & {$[46]$} \\
\hline
\end{tabular}

\section{Materials and Methods}

\subsection{Parameters Evaluation}

Raw water and treated water by coagulation-floculation were characterized and the following parameters are defined in the next subdivision: total alkalinity (TA), organic matter were measured according to the standard titrimetric methods [47], pH was obtained by a multi-parameter instrument (Jenway model 3540, Camlab, Cambridge, UK), turbidity measured using HANNA turbidimeter (Code: HI 98713, Hanna instruments, Cluj-Napoca, Romania), which is expressed in nephelometric turbidity units (NTU).

\subsection{Raw Water}

The initial characterization of the raw water studied (Oued El Athmania drinking water treatment plant, Mila) shows that all parameters accomplish the Algerian drinking water regulation: the $\mathrm{pH}(7.94)$, total alkalinity $(160 \mathrm{mg} \mathrm{CaCO} / \mathrm{L})$ and organic matter $\left(2.1 \mathrm{mg} \mathrm{O}_{2} / \mathrm{L}\right)$, except for turbidity (13 NTU), which exceeded the Algerian standard value (5 NTU) [48].

\subsection{Extraction of Active Components from Aloe vera}

Aloe vera was collected from a local region near a city located in the north east of Algeria called Mila. The choice of Aloe vera as a natural coagulant in this study was based on its effectiveness, thriftiness and its wide availability. The extraction of active coagulating agents from Aloe vera was carried according to the following steps:

- Drying: the Plant was Dried after Cleaning

The plant was harvested in the Mila region and dried in an oven at $60^{\circ} \mathrm{C}$ of temperature for $24 \mathrm{~h}$.

- Grinding and Sieving

After drying, a mortar and pestle were used to grind the plant to obtain small diameter seeds. The powder obtained was sieved using a fine sieve to obtain the final powder form with a diameter less than $0.35 \mathrm{~mm}$ (Fig. 1). 


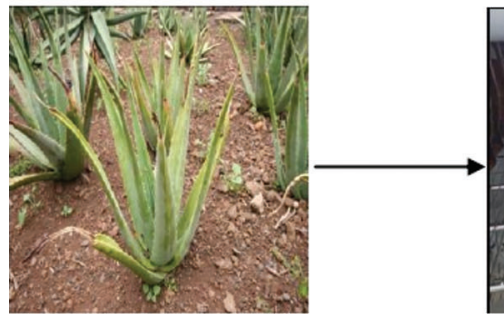

Aloe Vera

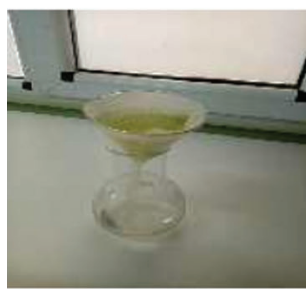

Filtration

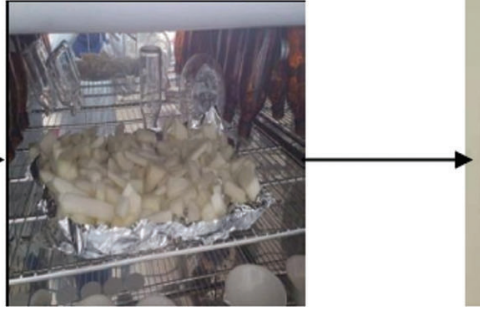

Drying

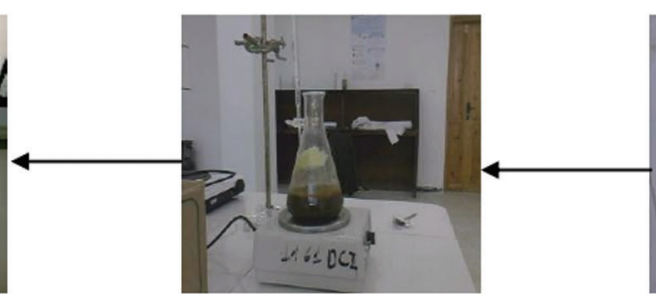

Treatment With Solvent
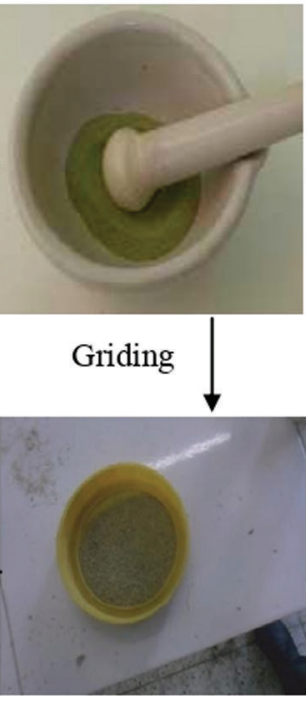

Powder Of Coagulant

Figure 1: Extraction of actives components from Aloe vera

$25 \mathrm{~g}$ of the obtained powder was used as bio-coagulant after different treatments such as sodium chloride solution $(\mathrm{NaCl})(0.25 \mathrm{M}, 0.5 \mathrm{M}, 1.0 \mathrm{M})$; base solution $(\mathrm{NaOH})(0.025 \mathrm{M}, 0.05 \mathrm{M}, 0.1 \mathrm{M})$; and acid solution $(\mathrm{HCl}(0.025 \mathrm{M}, 0.05 \mathrm{M}, 0.1 \mathrm{M})$, noting that the volume of each solvent was $1,000 \mathrm{~mL}$, after that the resulting solution was stirred for 20 min at $700 \mathrm{rpm}$ (see Fig. 1).

\section{- Filtration}

The solution was then allowed to settle for $30 \mathrm{~min}$. After filtration using standard filter (Porosity $<8 \mu \mathrm{m}$ ), the filtrate solution was kept in the cold room at $\pm 4^{\circ} \mathrm{C}$ and used as coagulant. The different obtained extracts were characterized in terms of proteins [49] and carbohydrates [50] which are summarized in Tab. 2.

Table 2: Characterization of the chemical extracts

\begin{tabular}{lll}
\hline & Proteins $(\mathrm{mg} / \mathrm{g})$ & Carbohydrates $(\mathrm{mg} / \mathrm{g})$ \\
\hline $\mathrm{NaCl}(\mathbf{0 . 5} \mathrm{M})$ & 2.063 & 2.3304 \\
$\mathrm{NaOH}(\mathbf{0 . 0 5} \mathrm{M})$ & 2.463 & 1.639 \\
$\mathrm{HCl}(\mathbf{0 . 0 5} \mathrm{M})$ & 1.963 & 1.786 \\
\hline
\end{tabular}

\subsection{Experimental Design}

A standard jar test apparatus (LI-JTA-125, LABARD, Labard instruments, Bengala, India) was used in the coagulation tests. Samples of the water $(500 \mathrm{~mL})$ were stirred at $160 \mathrm{rpm}$ for $3 \mathrm{~min}$ and during this time the coagulants $(\mathrm{AV}-\mathrm{NaCl} ; \mathrm{AV}-\mathrm{NaOH}$ et $\mathrm{AV}-\mathrm{HCl})$ were added at different concentrations from $0.1 \mathrm{~mL} / \mathrm{L}$ to $2.0 \mathrm{~mL} / \mathrm{L}$. The stirring speed was then lowered to $30 \mathrm{rpm}$ for $20 \mathrm{~min}$ after which the samples were allowed to stand for $30 \mathrm{~min}$.

The turbidity, $\mathrm{pH}$, total alkalinity and organic matter of the supernatant liquors were then measured noting that all values of each parameter were accompanied by an error bar with percentage. 
The turbidity was expressed in percentage removal:

Turbidity Removal $(\%)=\frac{\left(T_{I}-T_{R}\right) \times 100}{T_{I}}$

where $T_{I}$ and $T_{R}$ are the initial and residual turbidity, respectively.

\section{Results and Discussions}

\subsection{Characterization of Coagulant}

The infrared spectrum of Aloe vera was recorded with a Fourier-Transform Infrared Spectrometer (CHIMATZU Code: HI 98713, Chimatzu, Cluj-Napoca, Romania) (see Fig. 2).

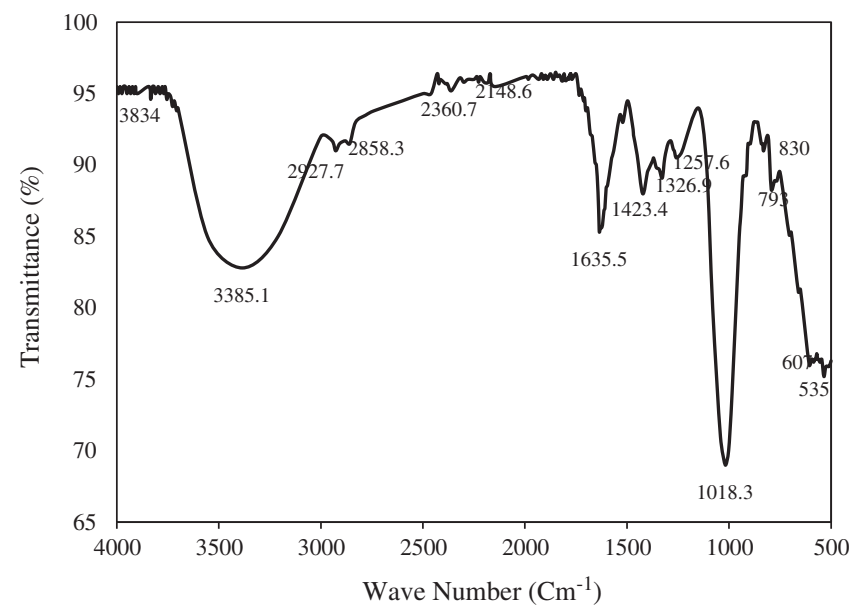

Figure 2: The infrared spectrum of Aloe vera

The active functional groups in Aloe vera are presented in Tab. 3.

The -NH-groups in the amides form intermolecular hydrogen bonds between the coagulant (Aloe vera) and the suspended matter to increase the efficiency of the coagulation process [51].

The presence of $\mathrm{CH}_{3}$ groups most likely indicates the presence of - $\mathrm{COOH}$ groups [52]. The carboxyl group provides adsorption sites for suspended solids during the coagulation process [53].

Table 3: Active functional groups in Aloe vera

\begin{tabular}{lll}
\hline Wave number $\left(\mathrm{cm}^{-1}\right)$ & Functional group & References \\
\hline 3385.1 & Hydroxyl group $\mathrm{OH}$ & {$[52,54,55]$} \\
2927.7 & $\mathrm{C}-\mathrm{H}$ asymmetric stretching in $\mathrm{CH}_{2}$ & {$[56-58]$} \\
2858.3 & $\mathrm{C}-\mathrm{H}$ symmetric stretching in $\mathrm{CH}_{2}$ & {$[57,59]$} \\
2360.7 & $\mathrm{C} \equiv \mathrm{N}$ & {$[34,60]$} \\
2148.6 & $\mathrm{C} \equiv \mathrm{C}$ & {$[34,60]$} \\
1635.5 & The carbonyl function $\mathrm{C}=\mathrm{O}$ (primary amides) & {$[29]$} \\
1257.6 & $\mathrm{COO}$ stretch Carboxylic acid salt & {$[61]$} \\
1423.4 & $\mathrm{CH}$ primary aromatic amines & {$[29]$} \\
1326.9 & $\mathrm{C}-\mathrm{N}$ group, aromatic primary amine stretch & {$[17,37,61]$} \\
1018.3 & $\mathrm{CO}$ group & {$[29,62]$} \\
$830,793,607$ and 535 & The aromatic CH out-of-plane deformation & {$[61]$} \\
\hline
\end{tabular}


3.2 Effect of Various Solvents as Chemical Activator on Turbidity, pH, Total Alkalinity and Organic Matter 3.2.1 Effect of $\mathrm{NaCl}$

The coagulant dose is the most important parameter in the turbidity removal process, because its effciency depends on the interaction between coagulant agent and cations present in water.

Fig. 3a shows the effect of coagulant dose on turbidity removal efficiency through the treament by $\mathrm{NaCl}$ : (AV-NaCl 0.25 M; AV-NaCl 0.5 M; AV-NaCl1 M), it clearly shows that the Aloe vera extract has an effect on turbidity removal.
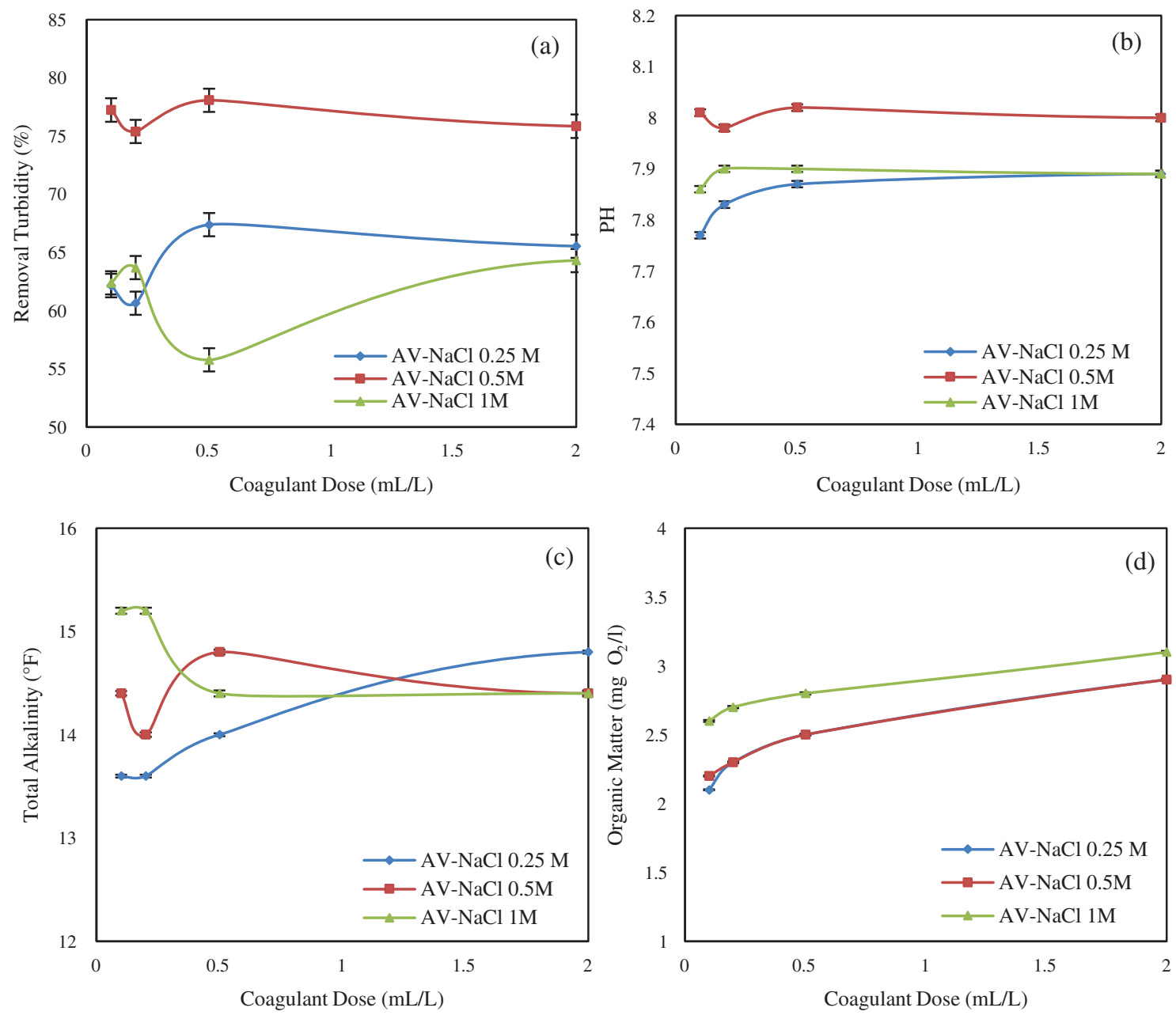

Figure 3: Effect of coagulant dosage on: (a) turbidity removal; (b) $\mathrm{pH}$; (c) total alkalinity; (d) organic matter (Effect of $\mathrm{NaCl}$ )

$\mathrm{NB}:{ }^{\circ} \mathrm{F}=10 \mathrm{mg} \mathrm{CaCO} / \mathrm{L}$

Among the concentrations tested, $0.5 \mathrm{M} \mathrm{NaCl}$ was the most effective one, producing the highest removal of turbidity compared to $0.25 \mathrm{M} \mathrm{NaCl}$ and $1 \mathrm{M} \mathrm{NaCl}$. The improvement of the coagulation activity for a concentration lower than $0.5 \mathrm{M}$ is due to salting as explained by the Debye-Huckel theory (increasing solvating power) [63], in this case, the ionic salt interacts directly with the active components (proteins) from the coagulant and increases the repulsion between the proteins, which reduces their solubility $[7,34,44]$. The decrease of the protein solubility in water with an increased salt concentration is known as the salting-out [63]. Salting-out is largely a function of the protein hydrophobicity, the addition of a 
higher concentrations than $0.5 \mathrm{M} \mathrm{NaCl}$ with high hydrophilicity leads to the sequestration of water molecules and will result in a decrease in protein solvation [7,34,44].

In this tests the percentage of turbidity removal was $67.38 \%, 78.07 \%, 64.3 \%$ when using $\mathrm{AV}-\mathrm{NaCl}$ $0.25 \mathrm{M}$; AV-NaCl $0.5 \mathrm{M}$ and AV-NaCl1 M, respectively.

The coagulant extracted from Aloe vera using salt solution $\mathrm{NaCl}$ (AV-NaCl $0.25 \mathrm{M}$; AV-NaCl $0.5 \mathrm{M}$; AV-NaCl $1 \mathrm{M}$ ) influenced slightly the $\mathrm{pH}$ and total alkalinity of water [34], and can be linked to the nature of treatment considered (Figs. $3 b$ and $3 c$ ).

Fig. 3d shows the effect of coagulant dosage on organic matter (AV-NaCl 0.25 M; AV-NaCl 0.5 M; AV$\mathrm{NaCl} 1 \mathrm{M}$ ). It shows that the addition of coagulant increases the concentration of organic matter in the solution. This increase can be explained by the organic nature of the coagulant, which contains a high content of organic matter, part of which is soluble in water [34,64]. It is worth noting that the high organic matter value were obtained when using $1 \mathrm{M} \mathrm{NaCl}$ as solvent, this being around $12 \mathrm{mg} \mathrm{O} / 2$.

\subsubsection{Effect of $\mathrm{NaOH}$}

Fig. 4a shows turbidity removal when using the Aloe vera coagulant extracted by $\mathrm{NaOH}$ at differents concentrations $(0.025 \mathrm{M}, 0.05 \mathrm{M}$ and $0.1 \mathrm{M})$. The $\mathrm{NaOH}$-extracted Aloe vera improved the water quality using the bioactive constituents from Aloe vera which gave $77.84 \%, 83.46 \%$ and $69.07 \%$ of turbidity removal for the coagulant AV-NaOH 0.025 M; AV-NaOH 0.05 M; AV-NaOH 0.1 M, respectively.
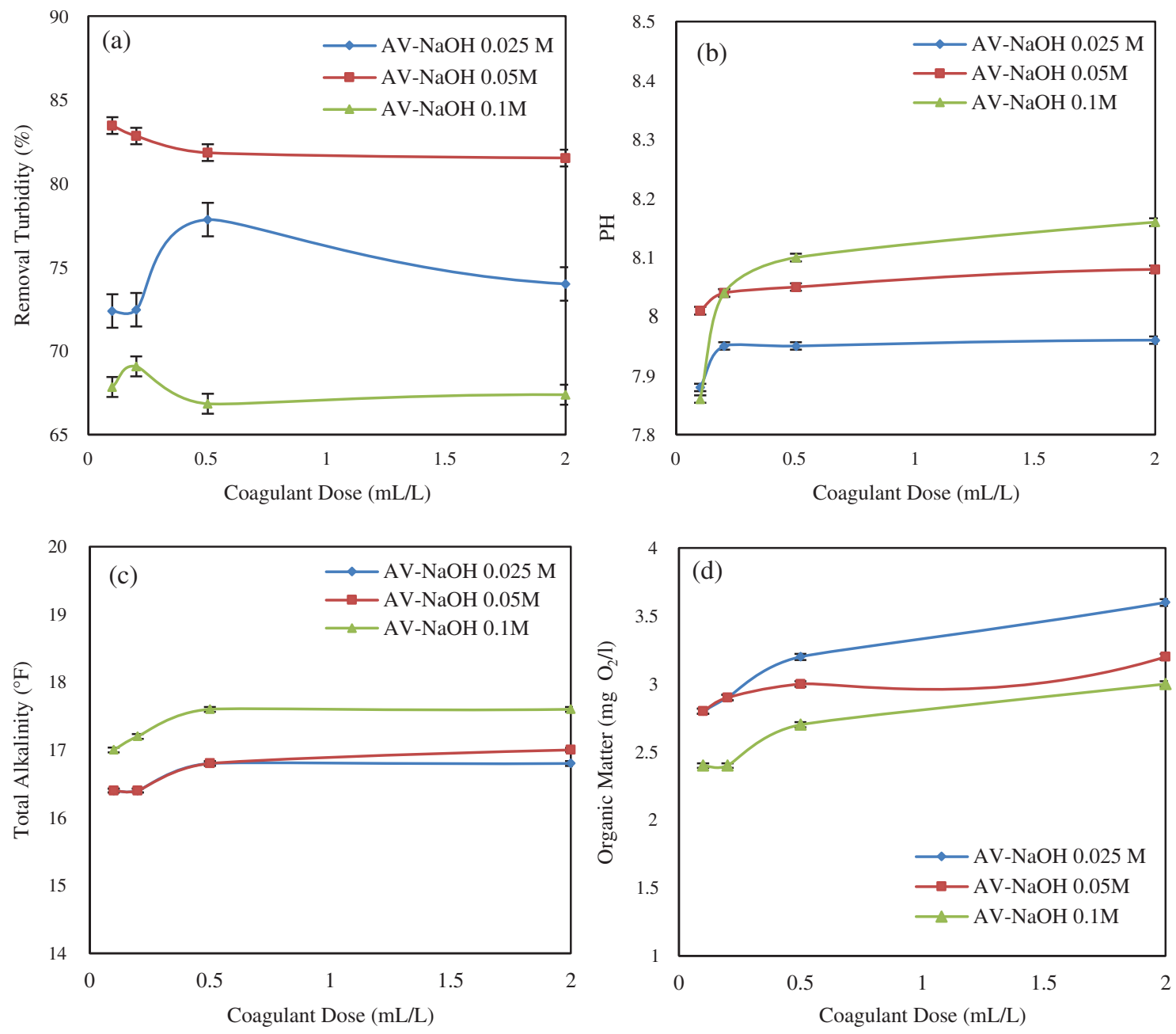

Figure 4: Effect of coagulant dosage on: (a) turbidity removal; (b) pH; (c) total alkalinity; (d) organic matter (Effect of $\mathrm{NaOH}$ ) 
In this study, $\mathrm{NaOH}$ concentration of $0.05 \mathrm{M}$ can be considered as the optimum concentration used for the extraction of active components from Aloe vera to improve the coagulation-flocculation process performance [44]. The decrease in turbidity removal for the coagulant AV-0.1 $\mathrm{M} \mathrm{NaOH}$ is due to denaturation of some active components which are proteins and hence this reduces the Aloe vera coagulant solubility $[34,44]$.

The characteristics of the water $(\mathrm{pH}$, total alkalinity and organic matter) after the Aloe vera treatment with $\mathrm{NaOH}$ (AV-NaOH $0.025 \mathrm{M}$; AV-NaOH $0.05 \mathrm{M}$; AV-NaOH 0.1 M) are shown in Figs. 4b-4d.

The increase in $\mathrm{pH}$ and total alkalinity can be explained by the nature of the solvent used $(\mathrm{NaOH})$ which causes a release of the hydroxide $\left(\mathrm{OH}^{-}\right)$.

The organic nature of the coagulant used $(\mathrm{AV}-\mathrm{NaOH})$ can increase the level of the organic matter in water (Fig. 4d). Whereas, a high organic matter values was obtained for $0.1 \mathrm{M} \mathrm{NaOH}$.

\subsubsection{Effect of $\mathrm{HCl}$}

Results of turbidity removal using various doses of Aloe vera are shown in Fig. 5a.
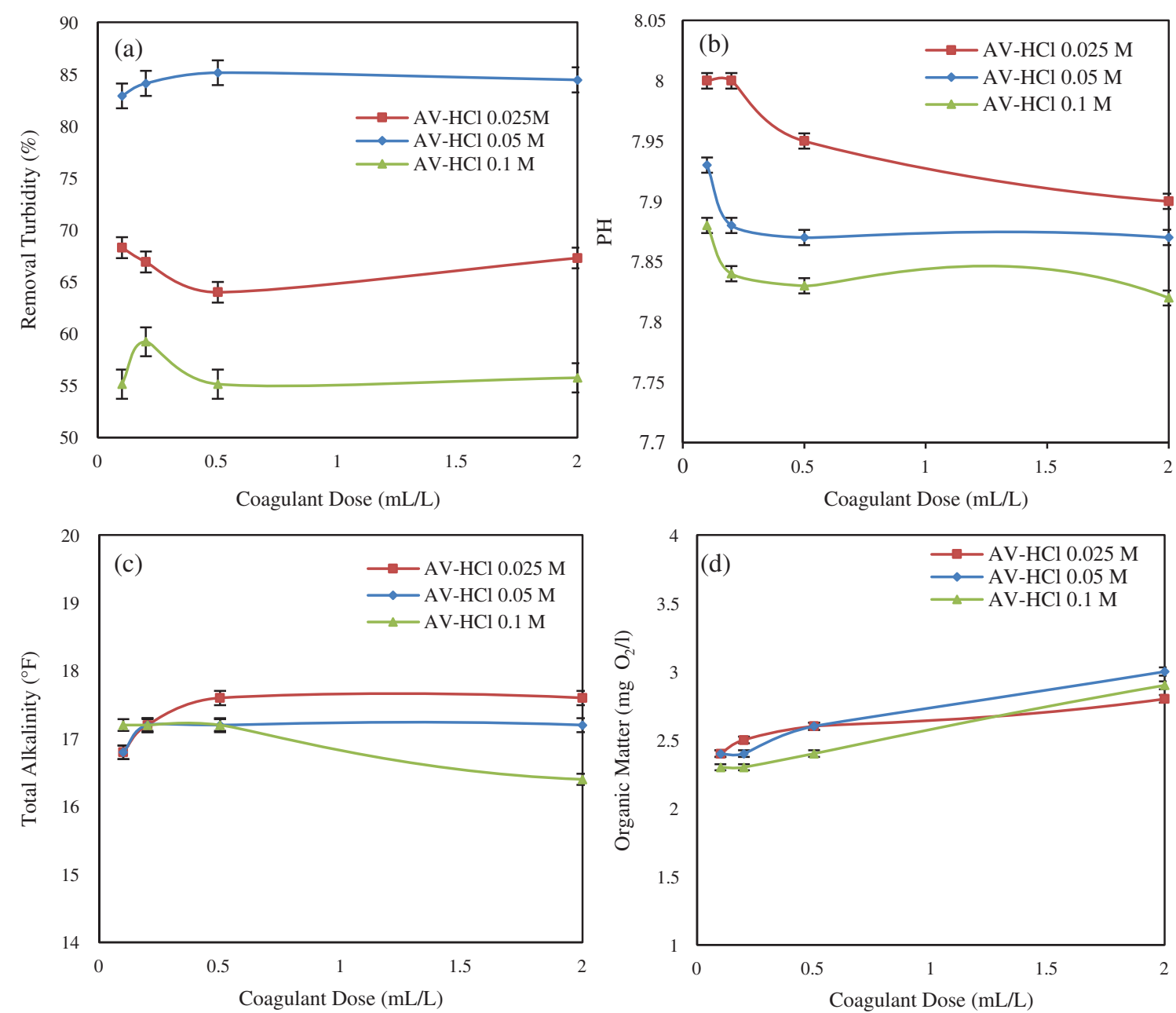

Figure 5: Effect of coagulant dosage on: (a) turbidity removal; (b) pH; (c) total alkalinity; (d) organic matter (Effect of $\mathrm{HCl}$ ) 
In this case, the turbidity removal of water was $68.3 \%, 85.15 \%$ and $59.23 \%$ after treatment by coagulant: AV- $\mathrm{HCl} 0.025 \mathrm{M}$; AV-HCl $0.05 \mathrm{M}$; AV-HCl $0.1 \mathrm{M}$, respectively. In this part, we have obtained a high solubility of active components at $0.05 \mathrm{M}$ [34].

Furthermore, Fig. $5 \mathrm{~b}$ shows the final $\mathrm{pH}$ values of water. The $\mathrm{pH}$ value is very important since the coagulation occurs within a specific $\mathrm{pH}$ range for the coagulant, the decrease in $\mathrm{pH}$ being related to the release of $\mathrm{H}^{+}$.

When using $\mathrm{HCl}$, the decrease in total alkalinity is related to the reaction between $\mathrm{H}^{+}$ions released by the $\mathrm{HCl}$ solvent and $\mathrm{HCO}_{3}{ }^{-}, \mathrm{OH}^{-}, \mathrm{CO}_{3}{ }^{2-}$ ions in water [34].

According to Fig. 5d, the final organic matter of water was increased gradually due to the increasing dosage of coagulant. AV- $\mathrm{HCl} 0.1 \mathrm{M}$ yielded the highest reading of organic matter at $12 \mathrm{mg} \mathrm{O} / \mathrm{L}$.

\section{Conclusion}

In the present work, a study has been conducted to investigate the feasibility of natural coagulant for the treatment of drinking water. It was observed that the Aloe vera is able to reduce the initial turbidity.

The residual turbidity measurements indicate that all solvents used have a remarkable effect on the extraction of active components from Aloe vera, which are responsible for coagulation. When using the $\mathrm{NaCl}, \mathrm{NaOH}$ and $\mathrm{HCl}$ solvents; the highest turbidity removal was $78.07 \%, 83.46 \%, 85.15 \%$, respectively. Thus, it can be concluded that: (1) AV-NaCl, AV-NaOH and AV-HCl can be used as coagulants, (2) the $\mathrm{HCl}$ solvent was the best extracting medium for the active components from Aloe vera when compared to $\mathrm{NaCl}$ and $\mathrm{NaOH}$.

The infrared spectrum confirms the presence of various functional groups, which are responsible for the coagulation process.

As perspectives: a comparative study of turbidity removal efficiency of different extraction methods of active coagulating agents from raw vegetable material. As well as the purification of the active components after extraction and used them in place of the raw form. Also a total characterization of raw vegetable material and the extracts obtained from this material.

Acknowledgement: This work was supported by the University Constantine 3.

Funding Statement: The authors received no specific funding for this study.

Conflicts of Interest: The authors declare that they have no conflicts of interest to report regarding the present study.

\section{References}

1. Bagwell, T. (2001). Handbook of public water systems. 2nd edition. New York: John Wiley \& Sons.

2. Desjardins, R. (1997). Traitement des eaux.pdf. 2e édition. Canada: Montréal, Presses Polytechnique de de Montréal.

3. Owodunni, A., Suzylawati, I. (2021). Revolutionary technique for sustainable plant-based green coagulants in industrial wastewater treatment-A review. Journal of Water Process Engineering, 42, 102096. DOI 10.1016/j. jwpe.2021.102096.

4. Degrémont, S. A. (2005). Mémento technique de l'eau, 10e édition. vol. 1. France: Degrémont.

5. Gautam, S., Saini, G. (2020). Use of natural coagulants for industrial wastewater treatment. Global Journal of Environmental Science and Management, 6, 553-578. DOI 10.22034/gjesm.2020.04.10.

6. Bachand, P., Lopus, E., Heyvaert, A., Werner, I., Bachand, S. (2010). Treatment with chemical coagulants at different dosing levels changes ecotoxicity of stormwater from the Tahoe basin, California, USA. Journal of 
Environmental Science and Health, Part A: Toxic/Hazardous Substances and Environmental Engineering, 45(2), 137-154. DOI 10.1080/10934520903425459.

7. Megersa, M., Gach, W., Beyene, A., Ambelu, A., Triest, L. (2019). Effect of salt solutions on coagulation performance of Moringa stenopetala and Maerua subcordata for turbid water treatment. Separation and Purification Technology, 221(5), 319-324. DOI 10.1016/j.seppur.2019.04.013.

8. Wang, Z. J., Wei, X. M., Yang, J. L., Suo, J. N., Chen, J. Y. et al. (2016). Chronic exposure to aluminum and risk of Alzheimer's disease: A metal-analysis. Neuroscience Letters, 610, 200-206. DOI 10.1016/j.neulet.2015.11.014.

9. Moulin, M. (2019). Biochemical, biophysical, and structural studies of seed proteins from Moringa oleifera and implications for traditional water purification (Ph.D. Thesis). Keele University.

10. Jahn, S. A. A. (1981). Traditional water purification in tropical developing countries: Existing methods and potential application. Eschborn, Germany: Deutsche Gesellschaft fur Technische Zusammenarbeit (GTZ).

11. Jahn, S. A. A. (1988). Using moringa seeds as coagulmts in developing countries. Journal AWWA, 80, 43-50. DOI 10.1002/j.1551-8833.1988.tb03052.x.

12. Jahn, S., Dinar, H. (1979). Studies on natural water coagulants in the Sudan, with special: Reference to Moringa oleifera seeds. Water SA, 5, 90-106. DOI 10.10520/AJA03784738_2011.

13. Madhukar, V. J., Yogesh, S. M. (2014). Assessment of feasibility of natural coagulants in turbidity removal and modeling of coagulation process. Desalination and Water Treatment, 52(31-33), 5812-5821. DOI 10.1080/ 19443994.2013.816875.

14. Vishali, S., Roshini, S. K., Samyuktha, M. R., Ashish, K. (2018). Towards zero waste production in the paint industry wastewater using an agro-based material in the treatment train. Environmental Monitoring and Assessment, 190(10), 587-595. DOI 10.1007/s10661-018-6904-z.

15. Scholes, A., Adenike, K., Aderonke, O. (2020). Efficacy of a natural coagulant protein from Moringa oleifera (Lam) seeds in treatment of Opa reservoir water, Ile-Ife, Nigeria. Heliyon, 6(1), e03335. DOI 10.1016/j. heliyon.2020.e03335.

16. Dolejs, P. (2013). Influence of coagulant/lime dosing sequence on treatment of soft humic waters. Water Supply, 13, 184-189. DOI 10.2166/ws.2013.0.

17. Kakoi, B., Wambua, J., Ndiba, P., Thiong, G. (2016). Banana pith as a natural coagulant for polluted river water. Ecological Engineering, 95(22), 699-705. DOI 10.1016/j.ecoleng.2016.07.001.

18. Bouchareb, R., Derbal, K., Özay, Y., Bilici, Z., Dizge, N. (2020). Combined natural/chemical coagulation and membrane filtration for wood processing wastewater treatment. Journal of Water Process Engineering, 37, 101521. DOI 10.1016/j.jwpe.2020.101521.

19. Rahmadyanti, E., Wiyono, A., Aritonang, N. (2020). Combination of phytocoagulant Moringa oleifera seeds and constructed wetland for coffee processing wastewater treatment. Journal of Engineering Science and Technology, 15(1), 728-745.

20. Maurya, S., Daverey, A. (2018). Evaluation of plant based natural coagulants for municipal wastewater treatment. 3 Biotech, 8(1), 76-79. DOI 10.1007/s13205-018-1103-8.

21. Narasiah, K. S., Vogel, A., Kramadhati, N. N. (2002). Coagulation of turbid waters using Moringa oleifera seeds from two distinct sources. Water Supply, 2, 83-88. DOI 10.2166/ws.2002.0154.

22. Chung, Y., Li, Y., Chen, C. (2005). Pollutant removal from aquaculture wastewater using the biopolymer chitosan at different molecular weights. Journal of Environmental Science and Health, Part A: Toxic/Hazardous Substances and Environmental Engineering, 40(9), 1775-1790. DOI 10.1081/ESE-200068058.

23. Ghebremichael, K. (2007). Overcoming the drawbacks of natural coagulants for drinking water treatment. Water Supply, 7(4), 87-93. DOI 10.2166/ws.2007.144.

24. Satyanarayan, S., Venerkar, A., Ramakant, P. (2004). Organic removals from highly proteinous wastewater from soya milk and tofu manufacturing plant. Journal of Environmental Science and Health, Part A: Toxic/Hazardous Substances and Environmental Engineering, 39(3), 759-771. DOI 10.1081/ESE-120027740. 
25. Pritchard, M., Craven, T., Mkandawire, T., Edmondson, A. S., Neill, J. G. O. (2010). A comparison between Moringa oleifera and chemical coagulants in the purification of drinking water-An alternative sustainable solution for developing countries. Physics and Chemistry of the Earth, 35(13-14), 798-805. DOI 10.1016/j. pce.2010.07.014.

26. Silveira, F. M. R., Baptista, A. T. A., Dutra, T. V. (2020). Application of Moringa oleifera Lam. fractionated proteins for inactivation of Escherichia coli from water. Water Science \& Technology, 81(2), 265-273. DOI 10.2166/wst.2020.094.

27. Fabris, R., Chow, C. W. K., Drikas, M. (2010). Evaluation of chitosan as a natural coagulant for drinking water treatment. Water Science \& Technology, 61(8), 2119-2128. DOI 10.2166/wst.2010.833.

28. Bouchareb, R., Derbal, K., Benalia, A. (2021). Optimization of active coagulant agent extraction method from Moringa oleifera seeds for municipal wastewater treatment. Water Science and Technology, 84(2), 393-403. DOI 10.2166/wst.2021.234.

29. Subramonian, W., Wu, T. Y., Chai, S. (2014). A comprehensive study on coagulant performance and floc characterization of natural Cassia obtusifolia seed gum in treatment of raw pulp and paper mill effluent. Industrial Crops \& Products, 61, 317-324. DOI 10.1016/j.indcrop.2014.06.055.

30. Rassol, A. M., Tavakoli, B., Chaibakhsh, N., Pendashteh, R. A., Mirroshandel, A. M. (2016). Use of a plant-based coagulant in coagulation-Ozonation combined treatment of leachate from a waste dumping site. Ecological Engineering, 90, 431-437. DOI 10.1016/j.ecoleng.2016.01.057.

31. Righetto, I., Al-juboori, R., Uzkurt, J., Mikola, A. (2021). Wastewater treatment with starch-based coagulants for nutrient recovery purposes: Testing on lab and pilot scales. Journal of Environmental Management, 284(11), 112021. DOI 10.1016/j.jenvman.2021.112021.

32. Yan, S., Nagendra, K., Yeong, T., Eshwaraiah, M., Nagasundara, R. (2016). Performance of conventional starches as natural coagulants for turbidity removal. Ecological Engineering, 94, 352-364. DOI 10.1016/j. ecoleng.2016.05.082.

33. Trivedi, P., Schaller, J., Gustafsson, J., Fardim, P. (2017). Supramolecular design of cellulose hydrogel beads. Journal of Renewable Materials, 5(5), 400-409. DOI 10.7569/JRM.2017.634143.

34. Benalia, A., Derbal, K., Panico, A., Francesco, P. (2019). Use of acorn leaves as a natural coagulant in a drinking water treatment plant. Water Research, 11(1), 1-12. DOI 10.3390/w11010057.

35. Dotto, J., Fagundes-klen, M. R., Veit, M. T., Palácio, S. M., Bergamasco, R. (2018). Performance of different coagulants in the coagulation/flocculation process of textile wastewater. Journal of Cleaner Production, 20, 656-665. DOI 10.1016/j.jclepro.2018.10.112.

36. Tetsuji, O., Aloysius, U. B., Wataru, N., Mitsumasa, O. (1999). Improvement of extraction method of coagulation active components from Moringa oleifera seed. Water Research, 33, 3373-3378. DOI 10.1016/ S0043-1354(99)00046-9.

37. Vishali, S., Karthikeyan, R. (2014). Cactus opuntia (ficus-indica): An eco-friendly alternative coagulant in the treatment of paint effluent. Desalination and Water Treatment, 56(6), 1489-1497. DOI 10.1080/19443994.2014.945487.

38. Ang, W. L., Mohammad, A. W. (2020). State of the art and sustainability of natural coagulants in water and wastewater treatment. Journal of Cleaner Production, 20, 121267. DOI 10.1016/j.jclepro.2020.121267.

39. Benalia, A., Derbal, K. (2015). Etude expérimentale et modélisation du processus de la coagulation floculation: application aux eaux destinée a la consommation (Master Thesis). Université Constantine 3.

40. Behera, B., Balasubramanian, P. (2019). Bioresource technology natural plant extracts as an economical and ecofriendly alternative for harvesting microalgae. Bioresource Technology, 283(2), 45-52. DOI 10.1016/j. biortech.2019.03.070.

41. Carvalho, M. S., Alves, B. R. R., Silva, M. F., Bergamasco, R., Coral, L. A. et al. (2016). $\mathrm{CaCl}_{2}$ applied to the extraction of Moringa oleifera seeds and the use for Microcystis aeruginosa removal. Chemical Engineering Journal, 304(3), 469-475. DOI 10.1016/j.cej.2016.06.101.

42. Klašnja, M., Antov, M., Škrbic, B., Marina, Š. (2009). Removal of water turbidity by natural coagulants obtained from chestnut and acorn. Bioresource Technology, 100(24), 6639-6643. DOI 10.1016/j.biortech.2009.06.047. 
43. Marina, B. S., Prodanovi, J. M., Dragana, V. K., Aleksandra, N. T., Mirjana, A. V. (2015). Extracts of fava bean (Vicia faba L.) seeds as natural coagulants. Ecological Engineering, 84(4), 229-232. DOI 10.1016/j. ecoleng.2015.09.008.

44. Abidin, Z. Z., Mohd, N. S., Madehi, N., Shafreeza, S. (2013). Optimisation of a method to extract the active coagulant agent from Jatropha curcas seeds for use in turbidity removal. Industrial Crops \& Products, 41(9), 319-323. DOI 10.1016/j.indcrop.2012.05.003.

45. Muthuraman, G., Sasikala, S. (2013). Removal of turbidity from drinking water using natural coagulants. Journal of Industrial and Engineering Chemistry, 20(4), 1727-1731. DOI 10.1016/j.jiec.2013.08.023.

46. Irma, A. E., Philippe, S., Abdoukarim, A., Alassane, Y. A., Pascal, A. C. et al. (2016). Evaluation of Aloe vera leaf gel as a natural flocculant: Phytochemical screening and turbidity removal trials of water by coagulation flocculation. Research Journal of Recent Sciences, 5(1), 9-15.

47. Rice, E. W., Baird, R. B., Eaton, A. D. (2012). Standard methods for the examination of water and wastewater. 22nd edition. Washington, DC, USA: American Public Health Association (APHA), American Water Works Association (AWWA) and Water Environment Federation (WEF).

48. Bouteflika, A. (2011). Parametres de qualite de l'eau de consommation humaine. Journal Officiel, 18, 6-9.

49. Bradford, M. (1976). A rapid and sensitive method for the quantitation microgram quantities of protein utilizing the principle of protein-dye binding. Analytical Biochemistry, 72, 248-254. DOI 10.1016/0003-2697(76)90527-3.

50. Dubois, M., Gilles, K., Hamilton, J., Rebers, A., Smith, F. (1956). Colorimetric method for determination of sugars and related substances. Analytical Chemistry, 28, 350-356. DOI 10.1021/ac60111a017.

51. Fatombi, J. K., Lartiges, B., Aminou, T., Barres, O., Caillet, C. (2013). A natural coagulant protein from copra (Cocos nucifera): Isolation, characterization, and potential for water purification. Separation and Purification Technology, 116(4), 35-40. DOI 10.1016/j.seppur.2013.05.015.

52. Yang, W., Shang, J., Sharma, P., Li, B., Liu, K. et al. (2019). Colloidal stability and aggregation kinetics of biochar colloids: Effects of pyrolysis temperature, cation type, and humic acid concentrations. Science of the Total Environment, 658, 1306-1315. DOI 10.1016/j.scitotenv.2018.12.269.

53. Yin, C. (2010). Emerging usage of plant-based coagulants for water and wastewater treatment. Process Biochemistry, 45(9), 1437-1444. DOI 10.1016/j.procbio.2010.05.030.

54. Thébault, M., Pizzi, A., Santiago-Medina, F., Al-Marzouki, F., Abdalla, S. (2017). Isocyanate-free polyurethanes by coreaction of condensed tannins with aminated tannins. Journal of Renewable Materials, 5(1), 21-29. DOI 10.7569/JRM.2016.634116.

55. Hamadi, Z., Chaid, R., Kebir, M., Amirou, S. (2020). Adsorption of Cr(VI) from aqueous solutions using Algerian pinus halepensis tannin foam. Polymer (Korea), 44, 425-435. DOI 10.7317/pk.2020.44.4.425.56.

56. Choudhary, M., Ray, M. B., Neogi, S. (2019). Evaluation of the potential application of cactus (Opuntia ficusindica) as a bio-coagulant for pre-treatment of oil sands process-affected water. Separation and Purification Technology, 209, 714-724. DOI 10.1016/j.seppur.2018.09.033.

57. Fatombi, J. K., Lartiges, B., Aminou, T., Barres, O., Caillet, C. A. (2013). A natural coagulant protein from copra (Cocos nucifera): Isolation, characterization, and potential for water purification. Separation and Purification Technology, 116, 35-40.

58. Ghahri, S., Mohebby, B., Pizzi, A., Mirshokraie, A. (2018). Improving water resistance of soy-based adhesive by vegetable tannin. Journal of Polymers and the Environment, 26(5), 1881-1890. DOI 10.1007/s10924-017-1090-6.

59. Santiago-Medina, F. J., Pizzi, A., Basso, M. C., Delmotte, L., Abdalla, S. (2017). Polycondensation resins by lignin reaction with (Poly) amines. Journal of Renewable Materials, 5(5), 388-399. DOI 10.7569/JRM.2017.634142.

60. Benalia, A., Derbal, K., Khalfaoui, A., Bouchareb, R., Panico, A. (2021). Use of Aloe vera as an organic coagulant for improving drinking water quality. Water, 13(15), 1-15. DOI 10.3390/w13152024.

61. Nharingo, T., Moyo, M. (2016). Application of Opuntia ficus-indica in bioremediation of wastewaters. A critical review. Journal of Environmental Management, 166, 55-72. DOI 10.1016/j.jenvman.2015.10.005. 
JRM, 2022, vol.10, no.3

62. Manholer, D. D., Tatiane, M., Souza, F. D., Ambrosio, E., Karoliny, T. et al. (2019). Coagulation/flocculation of textile effluent using natural coagulants extracted from Dillenia indica. Water Science \& Technology, 80(5), 979988. DOI 10.2166/wst.2019.342.

63. Baldwin, R. L. (1996). How Hofmeister ion interactions affect protein stability. Biophysical Journal, 71(4), 20562063. DOI 10.1016/S0006-3495(96)79404-3.

64. Nacoulma, G., Piro, J., Bayane, A. (2000). Etude de l'activité floculante d'un complexe protéine-mucilage végétal dans la clarification des eaux brutes. Journal de la Société Ouest-Africaine de Chimie, 9, 43-57. 